\title{
Changes in the levels of adipokines in newly diagnosed pulmonary tuberculosis patients in case of treatment failure
}

\author{
R. M. Yasinskyi ${ }^{* A-D}$, O. M. Raznatovska ${ }^{A}{ }^{A, C, E, F}$
}

Zaporizhzhia State Medical University, Ukraine

A - research concept and design; B - collection and/or assembly of data; C - data analysis and interpretation; D - writing the article;

$\mathrm{E}$ - critical revision of the article; $\mathrm{F}$ - final approval of the article

Key words:

\section{tuberculosis,}

treatment failure,

adipokines, leptin,

adiponectin.

\section{Zaporozhye}

medical journal

2020; 22 (2), 220-225

*E-mail:

phthisiologist@gmail. com
Improving the treatment efficacy for patients with newly diagnosed tuberculosis by reducing the number of treatment failure cases is very urgent issue nowadays.

Purpose. To define the characteristics of adipokines levels changes in newly diagnosed pulmonary tuberculosis patients in case of treatment failure by examining the levels of leptin, adiponectin and leptin/adiponectin ratio.

Materials and methods. A total of 58 patients with newly diagnosed pulmonary tuberculosis were the subject of this prospective study. The patients were divided into 2 groups: the first group was made up of 28 patients with the ineffectively treated newly diagnosed pulmonary tuberculosis; the second group (experimental group) consisted of 30 patients with successful treatment completion. The control group included 29 healthy voluntary donors. Changes in the levels of adipokines by measuring the blood serum leptin and adiponectin via enzyme linked immunosorbent assay using immunoassay analyzer Sirio S with "Mediagnost" kit (Germany) (ng/ml) were studied at the Scientific Medical Laboratory Center of Zaporizhzhia State Medical University. Leptin/ adiponectin ratio was calculated mathematically (relative units). Blood samples were collected after an overnight fasting. Statistica for Windows 13.0 (Copyright 1984-2018 TIBCO Software Inc., all rights reserved, Licence No. JPZ8041382130ARCN10-J) software was used for the statistical analysis.

Results. The following significant changes in the adipokines levels have been found in patients with newly diagnosed pulmonary tuberculosis with massive pulmonary lesions and destructions of over $3 \mathrm{~cm}$ in diameter and positive sputum smear. These patients will be diagnosed with ineffective treatment. At the beginning of the antimycobacterial therapy, there was a significant 12.7 times decrease in leptin and 1.4 times increase in adiponectin indicators and 21 times decrease in the leptin/adiponectin ratio. The levels of leptin, adiponectin and leptin/adiponectin ratio were significantly worse than similar levels in patients, who completed the treatment efficiently. The level of the leptin was slightly increased during the antimycobacterial therapy, albeit being significantly reduced, and the level of the adiponectin continued to increase significantly. The leptin/adiponectin ratio was significantly lower than that in patients who completed the treatment efficiently.

Conclusions. Patients with newly diagnosed pulmonary tuberculosis with the risk of treatment failure are diagnosed with severe disorders of adipocyte functional activity, that antimycobacterial chemotherapy could not even restore the balance to the adipokine system and smooth down resulting concomitant variations in immune response. The findings showed the prognostic value of the changes in leptin, adiponectin and leptin/adiponectin ratio indicators at the beginning of the treatment in relation to treatment failure among patients with newly diagnosed pulmonary tuberculosis.
Киючові слова: туберкульоз, невдача лікування, аАипокіни, мептин, адипонектин.

Запорізький медичний журнак. 2020. T. 22, № 2(119). C. 220-225

\section{Зміни рівнів адипокінів у хворих на неефективно Аікований уперше діагностований туберкульоз мегень}

\section{Р. М. Ясінський, О. М. Разнатовська}

Нині актуальною проблемою є підвищення ефективності лікування хворих із новими випадками захворювання на туберкульоз шляхом скорочення кількості невдач лікування.

Мета роботи - встановити особливості змін рівнів адипокінів у хворих на неефективно лікований уперше діагностований туберкульоз легень шляхом вивчення показників лептину, адипонектину та співвідношення лептин/адипонектин.

Матеріали та методи. У проспективне дослідження включили 58 хворих на вперше діагностований туберкульоз легень, яких поділили на 2 групи: у 1 увійшли 28 пацієнтів із неефективно лікованим уперше діагностованим туберкульозом легень; 2 група (порівняння) - 30 хворих, які згодом успішно завершили курс лікування. Контрольна група - 29 здорових донорів-волонтерів. Зміни показників адипокінів вивчали в Навчальному медико-лабораторному центрі Запорізького державного медичного університету шляхом дослідження рівнів лептину й адипонектину в сироватці крові методом твердофазного імуноферментного аналізу на приладі імуноферментний рідер SirioS із застосуванням наборів «Mediagnost» (ФPH), (нг/мл). Співвідношення лептин/адипонектин розраховували математично (ум. од.). Зразки крові хворих збирали вранці натще. Статистичний аналіз виконали, використовуючи програму Statistica for Windows 13.0 (Copyright 1984-2018 TIBCO Software Inc. all rights reserved, ліцензія № JPZ8041382130ARCN10-J).

Результати. У хворих на вперше діагностований туберкульоз легень із поширеним легеневим ураженням, деструкціями в легеневій тканині понад 3 см і з наявністю бактеріовиділення, в яких надалі визначили неефективність лікування, встановлені такі вірогідні зміни показників адипокінів. На початку антимікобактеріальної терапії відбувається вірогідне зниження лептину в 12,7 раза, зростання рівня адипонектину в 1,4 раза та зменшення співвідношення лептин/адипонектин у 21 раз. Рівні лептину, адипонектину та співвідношення лептин/адипонектин вірогідно гірші, ніж у хворих, які успішно завершили курс лікування. У процесі антимікобактеріальної терапії рівень лептину дещо зростав, але залишався вірогідно зниженим, 
а рівень адипонектину продовжував вірогідно зростати. Рівень співвідношення лептин/адипонектин вірогідно (у 3,4 раза) нижчий, ніж у хворих, які успішно завершили курс лікування.

Висновки. У хворих на вперше діагностований туберкульоз легень із ризиком неефективного лікування визначають тяжкі порушення функціональної активності показників адипоцитів, що навіть антимікобактеріальна хіміотерапія не здатна відновити баланс у системі адипокінів та нівелювати спричинені ними супутні порушення імунної відповіді. Результати вказують на прогностичне значення таких змін показників лептину, адипонектину та співвідношення лептин/ адипонектин на початку лікування щодо невдачі лікування хворих на вперше діагностований туберкульоз легень.

\section{Изменения уровней адипокинов у больных с неэффективно леченным впервые диагностированным туберкулезом легких}

\section{Р. Н. Ясинский, Е. Н. Разнатовская}

Повышение эффрективности лечения больных с новыми случаями заболевания туберкулезом путем сокращения количества неудач лечения - очень актуальная проблема.

Цель работы - установить особенности изменений уровней адипокинов у больных с неэффективно леченным впервые диагностированным туберкулезом легких путем изучения показателей лептина, адипонектина и соотношения лептин/ адипонектин.

Материалы и методы. В проспективное исследование включены 58 больных с впервые диагностированным туберкулезом легких, которых разделили на 2 группы: в 1 группу вошли 28 пациентов с неэффективно леченным впервые диагностированным туберкулезом легких; 2 группу (группа сравнения) составили 30 больных, которые в дальнейшем успешно завершили курс лечения. Контрольную группу составили 29 здоровых доноров-волонтеров. Изменения показателей адипокинов изучали в Учебном медико-лабораторном центре Запорожского государственного медицинского университета путем исследования уровней лептина и адипонектина в сыворотке крови методом твердофазного иммуноферментного анализа на приборе иммуноферментный ридер Sirio S с применением наборов «Mediagnost» (ФРГ), (нг/мл). Соотношения лептин/ адипонектин рассчитывали математически (усл. ед.). Образцы крови больных собирали утром натощак. Статистический анализ выполняли с использованием программы Statistica for Windows 13.0 (Copyright 1984-2018 TIBCO Softwarelnc. All rights reserved, лицензия № JPZ8041382130ARCN10-J).

Результаты. У больных с впервые диагностированным туберкулезом легких с распространенным легочным поражением, деструкциями в легочной ткани более 3 см и с наличием бактериовыделения, у которых в дальнейшем установили неэффективность лечения, определены следующие достоверные изменения показателей адипокинов. В начале антимикобактериальной терапии отмечено достоверное снижение уровня показателя лептина в 12,7 раза, повышение уровня показателя адипонектина в 1,4 раза и уменьшение соотношения лептин/адипонектин в 21 раз. Уровни лептина, адипонектина и соотношение лептин/адипонектин достоверно хуже, чем у больных, которые успешно завершили курс лечения. В процессе антимикобактериальной терапии уровень лептина несколько возрастал, однако оставался достоверно сниженным, а уровень адипонектина продолжил достоверно расти. Уровень соотношения лептин/адипонектин достоверно (в 3,4 раза) ниже, чем у больных, которые успешно завершили курс лечения.

Выводы. У больных с впервые диагностированным туберкулезом легких с риском неэффективного лечения определены тяжелые нарушения функциональной активности показателей адипоцитов, что даже антимикобактериальная химиотерапия не способна восстановить баланс в системе адипокинов и нивелировать вызванные ими сопутствующие сдвиги в иммунном ответе. Результаты указывают на прогностическое значение таких изменений показателей лептина, адипонектина и соотношение лептин/адипонектин в начале лечения относительно неудачи лечения больных с впервые диагностированным туберкулезом легких.

The World Health Organization's (WHO) Global Report states that 6,4 million of new tuberculosis cases had been diagnosed all over the world in the 2017 [1]. According to the findings of the State Institution "Department of Public Health of the Ministry of Healthcare of Ukraine", the rate of successful treatment of all tuberculosis cases remained the lowest among the countries of the European Region of WHO and was $76.5 \%$, when WHO's indicator was $85 \%$ [2]. In the Zaporizhzhia region, the indicator was $72.9 \%$. Through a statistical analysis, it was elucidated that one of the reasons of low treatment efficacy among tuberculosis patients is a treatment failure. The treatment failure indicator for Ukraine was $7.4 \%$, when the similar indicator for the Zaporizhzhia region went beyond the national one by 1.7 times and was $12.6 \%$.

The study of adipokines has attracted our attention while we were searching for the identification of pathogenetic mechanisms of treatment failure among patients with pulmonary tuberculosis.
Киючевые слова:

туберкулез, неудача лечения, аАипокины, мептин, адипонектин.

Запорожский медицинский журнал 2020. T. 22, № 2(119). C. $220-225$
So, as it is known, once mycobacterium tuberculosis penetrates a human body, under favourable conditions, they growth and pervade to various organs and body systems. In recent times, researchers suggest that adipocytes, which are influenced by a nutritional status, control metabolism and have much power in the functional activity of the immune system, might be one of the places of mycobacterium tuberculosis in the human body [3]. Also protracted mycobacterium tuberculosis persistence in the adipocytes might lead to a metabolic imbalance [4].

Among all the adipokines, leptin and adiponectin involvement in tuberculosis pathogenesis has been extensively studied nowadays $[5,6]$. Leptin is a key mediator of an energy metabolism, apart from that it mediates an appetite regulation, adipose tissue redistribution, increase in T-helpers 1 activity, lymphocytes and peripheral mononuclear cells proliferation and production of $y$-interferon $[7,8]$. Adiponectin promotes an increase in the body tissues irritability and T helper 1 products [9]. 
Table 1. The study groups distribution by age and sex

\begin{tabular}{l|l|l|l|} 
Patients & $\begin{array}{l}\text { The } 1^{\text {st }} \text { group } \\
(\mathbf{n}=\mathbf{2 8})\end{array}$ & $\begin{array}{l}\text { The } 2^{\text {nd }} \\
(\mathbf{n}=30)\end{array}$ & $\begin{array}{l}\text { Troup } \\
(\mathbf{n}=29)\end{array}$ \\
\hline Men & $20(71.4 \%)$ & $23(76.7 \%)$ & $19(65.6 \%)$ \\
Women & $8(28.6 \%)$ & $7(23.3 \%)$ & $11(34.4 \%)$ \\
\hline Average age, years & $46.04 \pm 2.09$ & $43.0 \pm 3.48$ & $42.2 \pm 2.9$ \\
\hline
\end{tabular}

However, the study results of the leptin and adiponectin level in tuberculosis patients are controversial enough. So, some researchers believe, that the blood levels of leptin in these patients are decreased, while the levels of adiponectin are elevated [10-12]. Keicho N. et al. [13] also recommend using a decreased leptin/adiponectin ratio (LAR) as a predictive measure to estimate a progressive course of tuberculosis, alongside the specified measurements.

Perna V. et al. [8] have determined in their study that in diagnosed tuberculosis, the level of leptin is reduced compared to the normal ranges of adiponectin indicators. Other researchers point that leptin levels in tuberculosis patients are not different from stated values [14], or even increased [15].

In the process of considering an adipokines impact on a treatment failure, N. Santucci, et al. [16] found that the levels of leptin are decreased, the levels of adiponectin are increased and particular decreasing in the LAR with tuberculous inflammation progresses.

Thus, improving the treatment efficacy for patients with newly diagnosed tuberculosis by reducing the number of treatment failure cases is very urgent issue nowadays. The literature review shows that adipokines are an important part of tuberculosis pathogenesis associated with the impact on both the metabolism of human body and the cell-mediated immunity.

The results of the studying the leptin and adiponectin involvement, which attract the interest of researchers more than anything else does nowadays, are controversial, especially in predicting/forecasting a newly diagnosed tuberculosis treatment failure. The changes in the adipokines level in patients with pulmonary pathology have been studied only in relation to chronic obstructive pulmonary disease (COPD) in Ukraine [17]. There has been no assessment of these indicators in tuberculosis patients in national literature. According to the literature data on the subject of pathogenetic importance of adipokines indicators in the specific process progression it could be argued that the study of this indicators changes in treatment failure is very important nowadays and also allows developing the case management algorithm to increase the treatment effectiveness among this patient population as a result.

\section{Aim}

To define the characteristics of adipokines levels changes in newly diagnosed pulmonary tuberculosis patients in case of treatment failure by examining the levels of leptin, adiponectin and leptin/adiponectin ratio.

\section{Materials and methods}

This prospective study included 58 patients with newly diagnosed pulmonary tuberculosis. Patients were divided into 2 groups: the first group was made up of 28 patients with the ineffectively treated newly diagnosed pulmonary tuberculosis; the second group (comparison group) consisted of 30 patients who completed the treatment successfully. The control group was made up of 29 healthy voluntary donors.

There were no significant age and sex differences between the groups (Table 1).

Changes in the blood serum adipokines levels were determined by leptin and adiponectin levels measurements via enzyme linked immunosorbent assay using immunoassay analyzer Sirio S with "Mediagnost" kit (Germany) (ng/ml) at the Scientific Medical Laboratory Center of Zaporizhzhia State Medical University. LAR was calculated mathematically (relative units). Blood samples were collected after an overnight fasting.

All the patients received an inpatient treatment in the Communal Institution "Zaporizhzhia Regional TB Clinical Dispensary" during 2017-2019. Patients were included in the study after voluntary signing an informed consent. The study was approved by Commission for Bioethics of Zaporizhzhia State Medical University (Protocol No. 1 dated 02.02.2017).

Inclusion criteria: newly diagnosed pulmonary tuberculosis, massive pulmonary tuberculous process (infiltrative and disseminated), pulmonary tissue destructions of over $3 \mathrm{~cm}$ in diameter and positive sputum smear.

Exclusionary criteria: other cases of the $2^{\text {nd }}$ category, chemoresistant tuberculosis, TB/HIV co-infection, comorbidities, age over 70 years, non-compliance with treatment.

Since the massive pulmonary tuberculous process was diagnosed in patients, an intensive phase for patients was 90 doses. Therefore, treatment efficacy was evaluated in 3 months according to the Unified Medical Care Protocol "Tuberculosis" (Order of the Ministry of Healthcare of Ukraine No. 620 dated 04.09.2014) [18]. Assessments of the changes in adipokines levels were performed at the beginning of the treatment by using antituberculosis drugs ( 0 doses) and after 3 months of the treatment (90 doses).

Statistica for Windows 13.0 (Copyright 1984-2018 TIBCO Software Inc., all rights reserved, License No. JPZ8041382130ARCN10-J) software was used for the statistical analysis. Normality of the quantitative indicators distribution was performed by the Shapiro-Wilk method. The study results were presented in a form of $\mathrm{M} \pm \mathrm{m}$, where $\mathrm{M}$ - the mean value, $\mathrm{m}$ - the mean error. $\mathrm{A}$ statistical significance of differences between groups was determined using the Student's method (since the normality of the quantitative indicators distribution was performed). The results considered to be significant only if the indicator of $P$ was lower than 0.05 .

\section{Results}

The study results of the adipokines levels are presented in Fig. 1-3.

When comparing the initial levels of the adipokines studied and LAR, it was found that the leptin levels (Fig. 1) were decreased in both groups of patients in comparison with the control group: in the $1^{\text {st }}$ group by 12.7 times, in the $2^{\text {nd }}$ group - by 3.8 times $(1.20 \pm 0.35 \mathrm{ng} / \mathrm{ml}$ and $4.10 \pm 1.09$ $\mathrm{ng} / \mathrm{ml}$, respectively, against $15.40 \pm 2.91 \mathrm{ng} / \mathrm{ml} ; \mathrm{P}<0.01$ ). Besides, the level of leptin was 3.3 times lower in the $1^{\text {st }}$ 
group compared to the $2^{\text {nd }}$ group $(1.2 \pm 0.35 \mathrm{ng} / \mathrm{ml}$ against $4.10 \pm 1.09 \mathrm{ng} / \mathrm{ml} ; \mathrm{P}<0.05)$.

The levels of adiponectin (Fig. 2) were also increased in both groups of patients in comparison to the control: by 1.4 times in the $1^{\text {st }}$ group and by 1.8 times in the $2^{\text {nd }}$ group $(17.20 \pm 1.25 \mathrm{ng} / \mathrm{ml}$ and $21.10 \pm 1.16 \mathrm{ng} / \mathrm{ml}$, respectively, against $12.00 \pm 1.06 \mathrm{ng} / \mathrm{ml} ; P<0.01)$. Wherein the levels of adiponectin in the $2^{\text {nd }}$ group 1,2 times exceeded that in the $1^{\text {st }}$ group $(21.10 \pm 1.16 \mathrm{ng} / \mathrm{ml}$ against $17.20 \pm 1.25 \mathrm{ng} / \mathrm{ml}$; $P<0.05)$.

According to the data obtained, a decrease in LAR was observed (Fig. 3) in both groups of patients as compared to the control: in the $1^{\text {st }}$ group by 21 times and in the $2^{\text {nd }}$ group by 6.1 times $(0.07 \pm 0.03$ relative units and $0.24 \pm 0.07$ relative units, respectively, against $1.47 \pm 0.32$ relative units; $P<0.001)$. In the $1^{\text {st }}$ group, this indicator was 3.4 times lower $(P<0.05)$ than that in the $2^{\text {nd }}$ group.

Assessment of adipokine indicators was performed after 3 months ( 90 doses) only in the $1^{\text {st }}$ and $2^{\text {nd }}$ groups. Analyzing the dynamics of the indicators studied it was found that the levels of leptin (Fig. 1) were elevated in all the patients regardless of the further treatment effect: in the $1^{\text {st }}$ group by 2 times $(2.40 \pm 0.46 \mathrm{ng} / \mathrm{ml}$ against $1.20 \pm 0.35 \mathrm{ng} / \mathrm{ml}$; $P<0.01)$ and in the $2^{\text {nd }}$ group by 1,4 times $(5.7 \pm 1.37 \mathrm{ng} /$ $\mathrm{ml}$ against $4.10 \pm 1.09 \mathrm{ng} / \mathrm{ml} ; \mathrm{P}<0.01)$. The levels of adiponectin (Fig. 2) increased in dynamics, but no significant differences were found. The LAR indicators (Fig. 3) were 1.7 times increased in the $1^{\text {st }}$ group $(0.12 \pm 0.03$ relative units against $0.07 \pm 0.03$ relative units; $P<0.05$ ).

Assessing the levels of adipokines in patients treated for 3 months ( 90 doses), it was found that, despite changes in the dynamics, the levels of leptin (Fig. 1) remained 6.4 times lower in the $1^{\text {st }}$ group and 2.7 times in the $2^{\text {nd }}$ group compared to the control $(2.40 \pm 0.46 \mathrm{ng} / \mathrm{ml}$ and $5.7 \pm 1.37$ $\mathrm{ng} / \mathrm{ml}$, respectively, against $15.4 \pm 2.91 \mathrm{ng} / \mathrm{ml} ; \mathrm{P}<0.05$ ). No significant differences were found between leptin levels in the $1^{\text {st }}$ and $2^{\text {nd }}$ groups.

The levels of adiponectin (Fig. 2) remained elevated in patients of both groups compared to the control group: by 1.6 times in the $1^{\text {st }}$ group, by 1.8 times in the $2^{\text {nd }}$ group $(18.8 \pm 1.76 \mathrm{ng} / \mathrm{ml}$ and $22.20 \pm 1.35 \mathrm{ng} / \mathrm{ml}$, respectively, against $12.00 \pm 1.06 \mathrm{ng} / \mathrm{ml} ; \mathrm{P}<0.01)$. No significant differences were found between adiponectin levels in the $1^{\text {st }}$ and $2^{\text {nd }}$ groups.

The LAR indicators (Fig. 3) remained lower in patients of both groups compared to the that values in the control group: by 12.3 times in the $1^{\text {st }}$ group and by 3.6 times in the $2^{\text {nd }}$ group $(0.12 \pm 0.03$ relative units and $0.41 \pm 0.14$ relative units, respectively, against $1.47 \pm 0.32$ relative units; $P<0.01)$. The LAR indicators were significantly 3,4 times lower in the $1^{\text {st }}$ group compared to the $2^{\text {nd }}$ group $(0.12 \pm 0.03$ relative units against $0.41 \pm 0.14$ relative units; $P<0.05$ ).

\section{Discussion}

This paper presents the study results of the adipokines levels (leptin, adiponectin and LAR) in patients with newly diagnosed pulmonary tuberculosis with generalized pulmonary involvement, lung tissue destruction of over $3 \mathrm{~cm}$ in diameter and positive sputum smear. Such changes in patients with newly diagnosed pulmonary tuberculosis are the risk factor for ineffective treatment, but determination

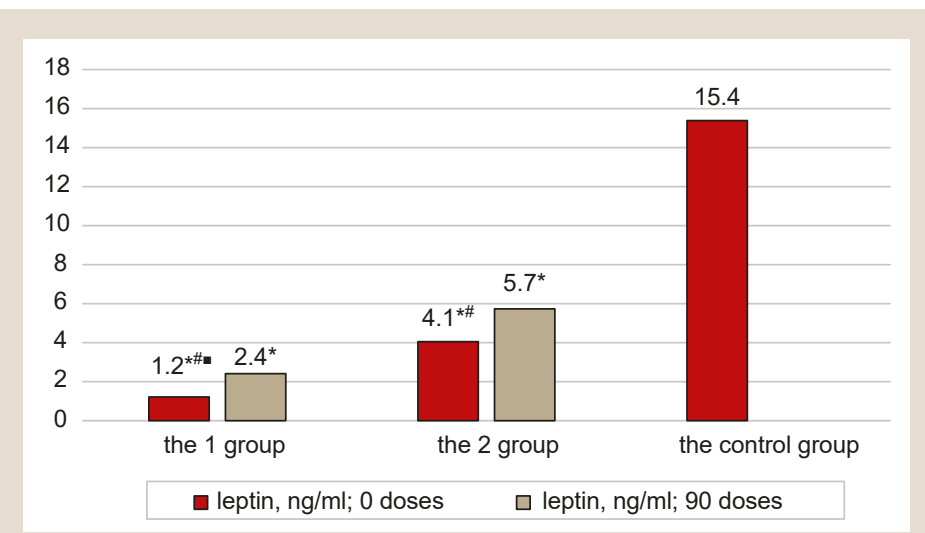

Fig. 1. Leptin levels in the groups.

*: significant difference between the levels of indicators related to the control group, $P<0.05$; $\#$ : significant difference between the levels of indicators in the dynamics within one group, $P<0.05$ : significant difference between the levels of indicators of the $1^{\text {st }}$ and $2^{\text {nd }}$ groups, $P<0.05$.

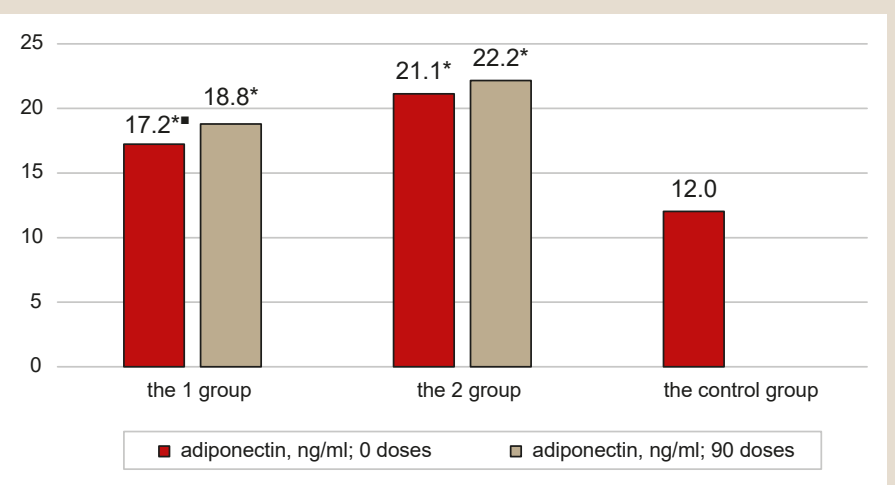

Fig. 2. Adiponectin levels in the groups.

*: the difference is significant between the indicators as compared to the control group, $P<0.05$; \#: the difference is significant between the indicators within one group in the dynamics, $P<0.05$ n: the difference is significant between the indicators of the $1^{\text {st }}$ and $2^{\text {nd }}$ groups, $P<0.05$.

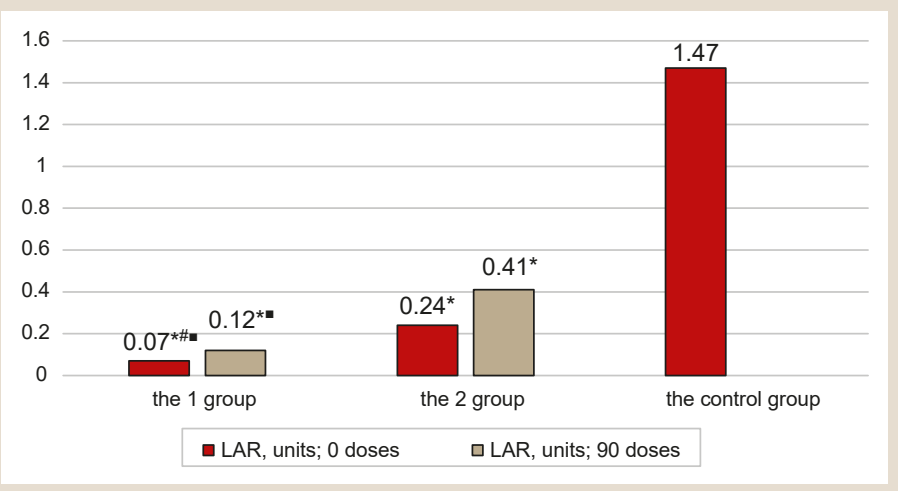

Fig. 3. Leptin/adiponectin ratio in the groups.

*: a significant difference between the levels of indicators relative to the control group, $P<0.05$ \#: a significant difference between the levels of indicators in the dynamics within one group, $P<0.05$; a: significant difference between the levels of indicators of the $1^{\text {st }}$ and $2^{\text {nd }}$ groups, $P<0.05$.

of adipokines levels in this category of patients is under-reported in the literature available.

As a result of the measurements, it was found that all the patients with newly diagnosed pulmonary tuberculosis presented significantly reduced baseline values of leptin and LAR, and significantly increased levels of adiponectin. The data obtained did not contradict the majority of other researchers' results $[11-13,16]$. 
It was established that patients with newly diagnosed pulmonary tuberculosis and the risk of ineffective treatment by clinical, radiological and bacteriological indexes, who were further diagnosed with ineffective treatment, presented more profound changes in adipokines levels demonstrating significantly lower levels of leptin, adiponectin and LAR than patients with newly diagnosed pulmonary tuberculosis successfully completed the antimycobacterial chemotherapy later.

In the dynamics, all the indicators of adipokines (leptin, adiponectin and LAR) were found to be increased in all the patients, regardless of further treatment results, that has been confirmed in several works $[8,19]$. In contrast to our results, Keicho $\mathrm{N}$. et al. found that leptin levels continued to decrease in dynamics and adiponectin levels increased [13].

Such changes occurred as a result of treatment, the number of mycobacteria and their activity decreased, which had an impact on the functional activity of adipocytes changes. In turn, changes in the activity of adipocytes had an effect on the immune cells functional activity, which in certain values of adipokines contributed to the positive course of tuberculous process in some patients (the $2^{\text {nd }}$ group) and protracted one in others (the $1^{\text {st }}$ group).

It was found that despite some increase in LAR among patients who subsequently were diagnosed with treatment failure, it remained significantly lower compared to the results of patients who completed the treatment successfully later. That is, we can agree with the data obtained by $N$. Keicho et al. [13] that the LAR has a great diagnostic value in predicting ineffective treatment.

However, the results showed that in patients with newly diagnosed pulmonary tuberculosis and generalized pulmonary involvement, lung tissue destructions of over $3 \mathrm{~cm}$ in diameter and positive sputum smear at the beginning of antimycobacterial therapy, the prognostic value of ineffective changes have divergent changes in adipokine indicators: decreased leptin levels and increased adiponectin levels. The LAR reduction has the prognostic value after 3 months of treatment (90 doses).

\section{Conclusions}

In patients with newly diagnosed pulmonary tuberculosis with generalized pulmonary involvement, lung tissue destructions of over $3 \mathrm{~cm}$ in diameter and positive sputum smear, who were further diagnosed with an ineffective treatment, the following significant changes in adipokines levels were established:

1. At the beginning of antimycobacterial therapy, there was a significant decrease in the levels of leptin by 12.7 times, an increase in the levels of adiponectin by 1.4 times and a decrease in the LAR by 21 times.

2. The levels of leptin, adiponectin and the LAR were significantly worse than in patients who successfully completed the treatment course.

3. In the process of antimycobacterial therapy, the levels of leptin was slightly increased, but remained significantly reduced, and the levels of adiponectin continued to increase significantly. The LAR was 3.4 times significantly lower than in patients who successfully completed the treatment course.
Thus, patients with newly diagnosed pulmonary tuberculosis with the risk of ineffective treatment were diagnosed with severe impairment of the adipocytes functional activity, when antimycobacterial chemotherapy could not even restore the balance to the adipokine system and smooth down resulting concomitant variations in immune response. The findings showed the prognostic value of the changes in leptin, adiponectin and leptin/adiponectin ratio indicators at the beginning of the treatment in relation to treatment failure among patients with newly diagnosed pulmonary tuberculosis.

Prospects for further scientific research. To develop an algorithm for managing this category of patients in order to reduce the number of treatment failure and increase the effectiveness of antimycobacterial therapy.

Conflicts of interest: authors have no conflict of interest to declare. Конфлікт інтересів: віАсутній.

Надійшка Ао редакції / Received: 09.09.2019

Після Аоопрацювання / Revised: 15.10.2019

Прийнято Ао Аруку / Accepted: 21.10.2019

Information about authors:

Yasinskyi R. M., MD, PhD, Associate Professor of the Department of Phthisiology and Pulmonology, Zaporizhzhia State Medical University, Ukraine.

ORCID ID: 0000-0003-4132-731X

Raznatovska O. M., MD, PhD, DSc, Professor, Head of

the Department of Phthisiology and Pulmonology, Zaporizhzhia

State Medical University, Ukraine.

ORCID ID: 0000-0003-2252-9063

\section{Відомості про авторів:}

Ясінський Р. М., канА. меА. наук, Аоцент каф. фтизіатрії і пульмонології, Запорізький державний медичний університет, Україна.

Разнатовська О. М., А-р меА. наук, професор, зав. каф. фтизіатрії і пульмонології, Запорізький Аержавний меАичний університет, україна.

\section{Сведения об авторах:}

Ясинский Р. Н., канА. меА. наук, Аоцент каф. фтизиатрии и пульмонологии, Запорожский государственный меАицинский университет, Украина.

Разнатовская Е. Н., А-р меА. наук, профессор,

зав. каф. фтизиатрии и пульмонологии, Запорожский

государственный медицинский университет, Украина.

\section{References}

[1] World Health Organization. (2018): Global tuberculosis report 2018. https://apps.who.int/iris/handle/10665/274453

[2] DU Tsentr hromadskoho zdorovia Ministerstva okhorony zdorovia Ukrainy, DZ Tsentr medychnoi statystyky Ministerstva okhorony zdorovia Ukrainy, \& Natsionalna medychna akademiia pisliadyplomnoi osvity im. P. L. Shupyka. (2019). Tuberkuloz v Ukraini [Tuberculosis in Ukraine]. Kyiv. https://phc.org.ua/sites/default/files/users/user90/TB surveillance_statistical-information_2018_dovidnyk.pdf [in Ukrainian].

[3] Ayyappan, J. P., Vinnard, C., Subbian, S., \& Nagajyothi, J. F. (2018). Effect of Mycobacterium tuberculosis infection on adipocyte physiology. Microbes and Infection, 20(2), 81-88. https://doi.org/10.1016/j. micinf.2017.10.008

[4] Agarwal, P., Khan, S. R., Verma, S. C., Beg, M., Singh, K., Mitra, K., Gaikwad, A. N., Akhtar, M. S., \& Krishnan, M. Y. (2014). Mycobacterium tuberculosis persistence in various adipose depots of infected mice and the effect of anti-tubercular therapy. Microbes and Infection, 16(7), 571-580. https://doi.org/10.1016/j.micinf.2014.04.006

[5] Santucci, N., Díaz, A., Bianchi, E., Spinelli, S., D’Attilio, L., Bongiovanni, B., Dídoli, G., Brandan, N., Nannini, L., Bay, M. L., \& 
Bottasso, O. (2014). Leptin does not enhance cell-mediated immune responses following mycobacterial antigen stimulation. The International Journal of Tuberculosis and Lung Disease, 18(8), 981-987. https:// doi.org/10.5588/ijtld.13.0780

[6] Ye, M., \& Bian, L. -F. (2018). Association of serum leptin levels and pulmonary tuberculosis: a meta-analysis. Journal of Thoracic Disease, 10(2), 1027-1036. https://doi.org/10.21037/jtd.2018.01.70

[7] Zubatkina, O. V., Dobrodeeva, L. K. \& Popov, A. A. (2015). Znachimost' urovnya leptina pri otsenke sostoyaniya adaptivnogo immuniteta [Significance of leptin level in assessment of adaptive immunity]. Ekologiya cheloveka, (12), 16-20. [in Russian].

[8] Perna, V., Pérez-Pérez, A., Fernández-Riejos, P., Polo-Padillo, J., Batista, N., Domínguez-Castellano, A., \& Sánchez-Margalet, V. (2013). Effective treatment of pulmonary tuberculosis restores plasma leptin levels. European Cytokine Network, 24(4), 157-161. https://doi. org/10.1684/ecn.2014.0346

[9] Lin, H. -H., Wu, C. -Y., Wang, C. -H., Fu, H., Lönnroth, K., Chang, Y. -C., \& Huang, Y. -T. (2017). Association of Obesity, Diabetes, and Risk of Tuberculosis: Two Population-Based Cohorts. Clinical Infectious Diseases, 66(5), 699-705. https://doi.org/10.1093/cid/cix852

[10] Santucci, N., D'Attilio, L., Kovalevski, L., Bozza, V., Besedovsky, H., del Rey, A., Bay, M. L., \& Bottasso, O. (2011). A Multifaceted Analysis of Immune-Endocrine-Metabolic Alterations in Patients with Pulmonary Tuberculosis. PLOS ONE, 6(10), Article e26363. https://doi.org/10.1371/ journal.pone.0026363

[11] Silva, D. R. Skupien, E. C., Lazzari, T. K. \& Coutinho, S. E. (2017, May 19-24). Relation of Leptin, TNF-Alpha and IL-6 with Respiratory and Peripheral Muscle Strength, and Nutritional Status in Active Pulmonary Tuberculosis. American Journal of Respiratory and Critical Care Medicine, 195, Article A2074. https://www.atsjournals.org/doi/pdf/10.1164/ ajrccm-conference.2017.195.1_MeetingAbstracts.A2074

[12] Yurt, S., Erman, H., Korkmaz, G. G., Kosar, A. F., Uysal, P., Gelisgen, R., Simsek, G., \& Uzun, H. (2013). The role of feed regulating peptides on weight loss in patients with pulmonary tuberculosis. Clinical Biochemistry, 46(1-2), 40-44. https://doi.org/10.1016/j.clinbiochem.2012.09.008

[13] Keicho, N., Matsushita, I., Tanaka, T., Shimbo, T., Hang, N. T. L., Sakurada, S., Kobayashi, N., Hijikata, M., Huu Thuong, P., \& Thi Lien, L. (2012). Circulating Levels of Adiponectin, Leptin, Fetuin-A and Retinol-Binding Protein in Patients with Tuberculosis: Markers of Metabolism and Inflammation. PLOS ONE, 7(6), Article e38703. https:// doi.org/10.1371/journal.pone. 0038703

[14] Kim, J. H., Lee, C. -T., Yoon, H. I., Song, J., Shin, W. G., \& Lee, J. H. (2010). Relation of ghrelin, leptin and inflammatory markers to nutritional status in active pulmonary tuberculosis. Clinical Nutrition, 29(4), 512-518. https://doi.org/10.1016/i.clnu.2010.01.008

[15] Zheng, Y., Ma, A., Wang, Q., Han, X., Cai, J., Schouten, E. G., Kok, F. J., \& Li, Y. (2013). Relation of Leptin, Ghrelin and Inflammatory Cytokines with Body Mass Index in Pulmonary Tuberculosis Patients with and without Type 2 Diabetes Mellitus. PLOS ONE, 8(11), Article e80122. https://doi.org/10.1371/journal.pone.0080122

[16] Santucci, N., D'Attilio, L., Besedovsky, H., del Rey, A., Bay, M. L., \& Bottasso, O. (2010). A Clinical Correlate of the Dysregulated Immunoendocrine Response in Human Tuberculosis. Neuroimmunomodulation, 17(3), 184-187. https://doi.org/10.1159/000258719

[17] Shpagin, I. S., Shpagina, L. A., Gerasimenko, O. N., Panacheva, L. A., Seledtsova, L. A. \& Sukhaterina, N. A. (2015). Nutritivnyi status pri arterial'noi gipertenzii i v sochetanii s khronicheskoi obstruktivnoi bolezn'yu legkikh [Nutritive status at arterial hypertensia and combined with chronic obstructive pulmonary disease]. Journal of Siberian Medical Sciences, (6). https://elibrary.ru/download/elibrary_25940257_48078286. pdf [in Russian].

[18] Ministry of Health of Ukraine. (2014, September 04). Pro zatverdzhennia ta vprovadzhennia medyko-tekhnolohichnykh dokumentiv zi standartyzatsii medychnoi dopomohy pry tuberkulozi [On approval and introduction of medical and technological documents on standardization of medical care in tuberculosis (No. 620)]. https://zakon.rada.gov.ual rada/show/ru/v0620282-14

[19] Kleynhans, L., Ruzive, S., Ehlers, L., Thiart, L., Chegou, N. N., Conradie, M., Kriel, M., Stanley, K., van der Spuy, G. D., Kidd, M., van Helden, P. D., Walzl, G., \& Ronacher, K. (2017). Changes in Host Immune-Endocrine Relationships during Tuberculosis Treatment in Patients with Cured and Failed Treatment Outcomes. Frontiers in Immunology, 8, 690. https://doi.org/10.3389/fimmu.2017.00690 